\title{
VIZUELNO PREDSTAVLJANJE U UDŽBENICIMA ZEMLJOPISA I POZNAVANJA PRIRODE U SRBIJI U PERIODU OD 1945. DO 1966. GODINE ${ }^{* *}$
}

Apstrakt: Predmet istraživanja je vizuelno predstavljanje u udžbenicima zemljopisa i poznavanja prirode za osnovnoškolski uzrast u periodu od 1945. do 1966. godine. Vizuelno predstavljanje podrazumeva jedan od ključnih strukturnih elemenata u udžbenicima. Cilj istraživanja je utvrđivanje karakteristika vizuelnog predstavljanja u udžbenicima zemljopisa i poznavanja prirode za osnovnoškolski uzrast u periodu od 1945. do 1966. godine. U radu su ukratko prikazani najvažniji rezultati i zaključci koji su dobijeni realizacijom ovog istraživanja. Imajući u vidu hronološki period kada su udžbenici zemljopisa i poznavanja prirode nastali i kada su se koristili, bili su od izuzetne važnosti za proces učenja. Proučavanje različitih tipova vizuelnog predstavljanja u udžbenicima kako nekad tako i danas je od izuzetne važnosti za unapređivanje nastavnog procesa.

Ključne reči: vizuelno predstavljanje, ilustrativni materijal, pedagoška prošlost, udžbenici zemljopisa, udžbenici poznavanja prirode.

\section{UVOD}

Utemeljenjem nacionalnih obrazovnih sistema tokom XIX veka, udžbenici su postali ključni materijal i didaktički resurs u obrazovanju mladih generacija. Znatno kasnije, kao takvi, oni postaju predmet proučavanja i značajan izvor informacija za istraživače iz oblasti obrazovanja (Ilić Rajković i Senić Ružić, 2016).

\footnotetext{
*Đurđa Petrović, petrovicdjurdja7@gmail.com

** Ovaj rad je nastao iz master rada istog naziva koji je odbranjen u septembru 2018. godine na Odeljenju za pedagogiju Filozofskog fakulteta Univerziteta u Beogradu.
} 
Ukoliko udžbenike posmatramo u širem, društvenom kontekstu, oni predstavljaju instrument znanja i instrument moći (Apple, 2000; Badanelli et al., 2009; citirano kod Ilić Rajković i Senić Ružić, 2016, str. 558). Iako su oni usklađeni sa državnim kurikulumom, udžbenici svojim sadržajima i strukturom konstituišu stvarni kurikulum školi koji ne odgovara uvek u potpunosti propisanim ciljevima i sadržajima (Badanelli et al., 2009 citirano u: Ilić Rajković, Senić Ružić, 2016, str. 558).

Različite discipline bave se istraživanjem udžbenika. Ukoliko posmatramo iz pedagoške perspektive, može se istaći da se udžbenici mogu proučavati kao nastavno sredstvo, kao pedagoški i didaktički instrument koji je namenjen prenošenju znanja, kao kulturni proizvod koji predstavlja „ogledalo društva“, kao i politički i ideološki instrument kreiran da prenese, učvrsti određene vrednosti, norme i verovanja (Mahamud, 2014: 32).

Ilustrativnom materijalu pripada značajno mesto $\mathrm{u}$ strukturi vantekstualnih komponenata koje treba da obezbede usvajanje informacija datih u udžbeniku i da podstaknu učenika na učenje. Zujev (Zujev, 1988) navodi da - baziran na umetničkoj osnovi - ilustrativni materijal, raspolaže određenim vaspitnim i obrazovnim mogućnostima.

Namera je autorki da u ovom radu daju teorijsko-metodološku osnovu sopstvenog istraživanja i da ukratko predstave i razmotre najvažnije rezultate do kojih su došle realizacijom istraživanja. $\mathrm{S}$ tim u vezi, u prvom delu rada prezentirana je njegova teorijsko-metodološka osnova. U drugom delu rada posebna pažnja posvećena je rezultatima podeljenim u tri podnaslova prema zadacima istraživanja. 


\section{TEORIJSKO-METODOLOŠKA OSNOVA ISTRAŽIVANJA}

\section{Predmet istraživanja}

Predmet ovog istraživanja je vizuelno predstavljanje u udžbenicima zemljopisa i poznavanja prirode za osnovnoškolski uzrast u periodu od 1945. do 1966. godine.

U tekstu koji sledi biće detaljnije prezentirana proučavanja udžbenika, zatim sledi razmatranje osnovnih pojmova sadržanih u predmetu ovog istraživanja, potom obrazlaganje opredeljenja za period u kojem je ono uokvireno. Pored navedenog, ukazaće se i na važnost proučavanja vizuelnog predstavljanja u udžbenicima i objasniti razlozi opredeljenja za proučavanje udžbenika zemljopisa i poznavanja prirode za osnovnoškolski uzrast.

Značaj istorijskog proučavanja udžbenika.

Udžbenici prenose globalno shvatanje istorije i pravila društva, kao i norme koje se odnose na život sa drugim ljudima. Pored toga, „udžbenici odražavaju tradicije koje je društvo formiralo decenijama ili vekovima, doprinose razvijanju samopoštovanja kod pojedinca, ali i označavaju granične linije svakog društva koje se razmatra“ (Pingel, 2010: 7). Proučavanje udžbenika je izuzetno korisno u smislu otkrivanja mehanizama putem kojih su autoriteti pokušavali da kontrolišu proces obrazovanja (Ilić Rajković i Senić Ružić, 2016).

Za potrebe ovog istraživanja, biće objašnjen sam pojam udžbenika. Prema sociofunkcionalnom kontekstu, Hene definiše udžbenik kao medij sociokulturnog znanja koji reprezentuje sliku datog društva koja je na mnoge načine filtrirana, prestrukturirana i kontrolisana (Höhne, 2003; citirano u: Ilić 
Rajković i Senić Ružić, 2016, str. 557). Procese u okviru kojih se udžbenik konstruiše i egzistira Hene naziva ,arenom diskursa“, gde su diskursi određeni kao „prakse koje sistematski obrazuju objekte o kojima govore“ (Fuko, 1998; citirano u: Ilić Rajković i Senić Ružić, 2016, str. 558). Kao rezultat tih procesa, udžbenik je multidimenzionalni produkt koji je istovremeno: informatorium, pedagogicum, politicum i constructorium. Imenovanjem ovih dimenzija ukazuje se na sociokulturne karakteristike i na poreklo udžbeničkog znanja (Höhne, 2003; citirano u: Ilić Rajković i Senić Ružić, 2016, str. 558).

Ovakvo shvatanje udžbenika omogućuje da usmerenost na ono šta su udžbenici imali za cilj da podstiču kada su dizajnirani. „Da li su to prvenstveno izvori informacija, da li podstiču razvoj čitanja, pisanja ili veštine kritičkog razmišljanja? Da li pružaju etičke modele ponašanja ili promovišu patriotizam?““(Fleming, 1989/90; citirano u: Pingel, 2010, str. 8).

Vizuelno predstavljanje gradiva u udžbenicima.

U prošlosti je u udžbenicima dominirala naracija, ali se vremenom dizajn školskih udžbenika značajno promenio. Udžbenici su sada puni slika, mapa, karikatura, fotografija i crteža. Pingel navodi da je „značajno istražiti funkciju ilustracija i utvrditi da li one dodaju nove karakteristike, da li menjaju ugao posmatranja ili dopunjuju tekst“" (Pingel, 2010: 48).

Ilustracije često utiču na emocije posmatrača i stimulišu ih da izraze svoja osećanja. Zbog toga ilustracije imaju veću verovatnoću da podstiču duboko ukorenjene predrasude, da pomažu formiranje slika u umu učenika, što je dugotrajnije od pisanog teksta. „Proučavanje ilustracija u udžbenicima 
može pokazati da se one koriste za prenošenje poruke koja nije vidljiva na prvi pogled“ (Pingel, 2010: 48).

Ikonička sredstva.

Pod pojmom ikonička sredstva (slikovna sredstva, ilustracije) podrazumevaju se specifična sredstva saopštavanja. To su: „fotografije, reprodukcije likovnih dela, crteži, sheme, dijagrami, grafikoni, ekonomski 'kolači', histogrami, mape, karte, strip, priča u slikama, grafička naglašavanja“" (Ivić i sar., 2008: 94).

Prema svojoj dominantnoj funkciji, vizuelno predstavljanje je očigledni oslonac mišljenja koji treba da poveća saznajni, idejni, estetski i emocionalni aspekt školskog gradiva u udžbeniku (Zujev, 1988). Stoga, utvrđivanje tipova vizuelnog predstavljanja u udžbenicima zemljopisa i poznavanja prirode posmatran je kao neizostavni deo ovog istraživanja. Pored toga, važno je ispitati kakvo su mesto ilustracije zauzimale u priručnicima i metodskim uputstvima za učitelje, odnosno, kako je bilo predviđeno njihovo korišćenje u nastavi.

U okviru istraživanja, može se govoriti o tri funkcije ikoničkih sredstava izražavanja a to su: saznajna, motivaciona i afektivna $\mathrm{i}$ estetska funkcija. Vizuelni prikazi koji ostvaruju saznajnu funkciju treba da pruže jasnije, preciznije i očiglednije izlaganje nastavnog gradiva. „Ikonička sredstva izražavanja mogu da doprinesu motivacionoj i afektivnoj funkciji udžbenika, tako što će izazvati emocije kod posmatrača, bilo dopadanja ili nedopadanja, samilosti, empatije, gneva, ugroženosti i slično“ (Ivić i sar., 2008: 95). Pre svega, treba da zainteresuje učenike za nastavni sadržaj. Takođe, ilustracije mogu da ostvaruju estetsku i dekorativnu funkciju sa 
ciljem podizanja nivoa estetske vrednosti udžbenika u celini i mogu doprineti estetskom vaspitanju učenika (Ibid).

Značaj istorijskog proučavanja udžbenika zemljopisa i poznavanja prirode.

Prilikom odabira udžbenika za ovaj uzrast, uzeta su u obzir neka savremena istraživanja procesa usvajanja pojmova u nastavi, kao i ideja Vigotskog da je osnovni cilj razvoja u školskom uzrastu razvoj naučnih pojmova kroz sistematsko obučavanje. Stoga, opredeljenje je da se prati vizuelno predstavljanje u udžbenicima zemljopisa i poznavanja prirode. Stav je taj da je potrebno ispitivati koji se pojmovi učenicima vizuelno predstavljaju i na koji način. Odabirom ovih predmeta koji se izučavaju u navedenim razredima dobijena je specifična mogućnost analiziranja prvih pouka uz pomoć kojih učenici ulaze u osnove saznavanja sveta koji ih okružuje.

Savremena shvatanja ovih nastavnih predmeta polaze od toga da realno predstavljeni pojmovi učenicima omogućuju bolje razumevanje života i prirode. Takođe, treba da im ponude primenljiva znanja neophodna za život pojedinca, znanja koja su od šireg značaja za društvo u kojem pojedinac živi i radi. Izučavanje zemljopisa i poznavanja prirode ima praktičnu primenu u raznim oblastima života ljudi, učenicima omugućava da razumeju i shvate ekonomska i politička kretanja u svetu. Stoga, zaključeno je da je korisno ispitati kako se vizuelno predstavljaju osnovni pojmovi u ovim udžbenicima. „Vizuelno predstavljanje nastavnog sadržaja veoma je važno za razvoj mentalnih funkcija, a posebno za razvoj mišljenja“ (Kocić, 2001: 149). 
Hronološki okvir istraživanja.

Donja hronološka granica je 1945. godina. U tom periodu, važan cilj učenja bio je vaspitanje novog čoveka u skladu sa potrebama industrijskog društva. „Zdravlje, obrazovanje, blagostanje i socijalna sigurnost smatrani su velikim dobrom kojem je trebalo težiti“ (Čalić, 2013: 231).

Karaktersitike nove obrazovne politike su sledeće: odvajanje škole od crkve; izgradnja jedinstvenog školskog sistema; produžavanje obaveznog i besplatnog osnovnog obrazovanja; razgranavanje mreža svih vrsta i nivoa škola; postavljanje celokupnog vaspitno-obrazovnog rada na marksističku osnovu i u duhu tekovina narodnooslobodilačke borbe i socijalističke revolucije. U prvim godinama materijalni i politički razlozi uslovili su centralizovano i administrativno rukovođenje svim društvenim poslovima pa tako i prosvetom (Tešić i sar., 1980).

Socijalistička modernizacija proizvela je opštu promenu i transformaciju elita. Takođe, društvena struktura promenila se usled revolucije u obrazovanju (Čalić, 2013). Postalo je jasno da je ukupan društveni razvitak moguć samo ako se ne zaostane u oblasti obrazovanja. To je zahtevalo da se obrazovanje ne tretira izolovano i ne usmerava budžetom, već da postane ravnopravni i integralni deo društvene reprodukcije. Zakonom o finansiranju obrazovanja i vaspitanja i zajednicama obrazovanja iz 1966, formiraju se samostalna i stabilna sredstva za obrazovanje i ustanovljava poseban doprinos iz ličnih dohodaka građana (doprinos za obrazovanje). Sa druge strane, konstituišu se zajednice obrazovanja u kojima se na samoupravnoj osnovi omogućuje neposredno povezivanje obrazovanja sa 
privredom i ostalim oblastima društvene delatnosti. To će uticati na dalju politiku reforme i izgrađivanja školskog sistema (Tešić i sar., 1980).

\section{Cilj i zadaci istraživanja}

Cilj istraživanja jeste utvrđivanje karakteristika vizuelnog predstavljanja u udžbenicima zemljopisa $\mathrm{i}$ poznavanja prirode za osnovnoškolski uzrast u periodu od 1945. do 1966. godine. Iz ovako postavljenog cilja proizilaze sledeći zadaci istraživanja:

- predstaviti udžbenike zemljopisa i poznavanja prirode u njihovom širem, društveno-političkom, i užem, teorijsko-pedagoškom kontekstu;

- utvrditi tipove vizuelnog predstavljanja u udžbenicima zemljopisa i poznavanja prirode za osnovnoškolski uzrast;

- razumeti i objasniti kvalitet vizuelnog predstavljanja u udžbenicima zemljopisa $\mathrm{i}$ poznavanja prirode $\mathrm{s}$ aspekta njihove didaktičke funkcionalnosti;

- istražiti stanovište o vizuelnom predstavljanju sadržanom u praktičnim priručnicima za učitelje (štampanim uz udžbenike).

\section{Uzorak istraživanja}

Uzorak istraživanja obuhvata udžbenike zemljopisa i poznavanja prirode koji su korišćeni u periodu od 1945. do 1966. godine. Analizirani su udžbenici koji su korišćeni na teritoriji Republike Srbije.

Istraživanjem je obuhvaćeno 27 udžbenika, $\mathrm{i}$ to u svim dostupnim izdanjima, što čini ukupno 61 primerak udžbenika zemljopisa i poznavanja prirode. Pored toga, istraživanjem je obuhvaćeno i 6 priručnika za učitelje. 
Ovakav pristup omogućava uvid u to da li svi udžbenici prenose znanja i poruke na isti način, da li se i koliko razlikuju od ostalih itd. S obzirom na to da je u periodu koji se razmatra u ovom radu postojao državni monopol samo nekoliko izdavačkih kuća - postojala je mogućnost utvrđivanja i sakupljanja $100 \%$ uzorka.

Metoda, tehnike, instrumenti, način obrade i analiza rezultata istraživanja

Metod za proučavanje teme jeste istorijski. Primenjena tehnika analize sadržaja istorijskih izvora i naučne literature omogućuje praćenje vizuelnog predstavljanja u udžbenicima zemljopisa i poznavanja prirode za osnovnoškolski uzrast u periodu od 1945. do 1966. godine. Centralni deo analize zauzimaju udžbenici zemljopisa i poznavanja prirode, pri čemu se ikoničko sredstvo izražavanja koristi kao jedinica analize. $\mathrm{Na}$ taj način pokušano je utvrđivanje tipova vizuelnog predstavljanja u ovim udžbenicima. Pored toga, objašnjavano je vizuelno predstavljanje u udžbenicima zemljopisa i poznavanja prirode s aspekta njihove didaktičke funkcionalnosti. Da bi uspelo istraživanje i pozicije udžbenika u kontekstu u kojem se javljaju, neophodna je bila analiza zvanične dokumentacije namenjene organizaciji škole i nastave.

Korišćeni instrumenti jesu evidencione liste, preuzete od Janka i Nekta (Janko \& Knecht, 2014) i nadograđene za potrebe ovog istraživanja. Janko i Nekt (Janko \& Knecht, 2014) su razvili istraživački instrument sistem kategorija - za sortiranje pojedinačnih tipova vizuelnih prikaza $u$ udžbenicima geografije, kao i za procenu njihovih instruktivnih kvaliteta. Njihov instrument omogućava praćenje kvaliteta $\mathrm{s}$ obzirom na njihovu apstraktnost, prikladnost natpisa ispod ikoničkih sredstava izražavanja i 
povezanost ilustrativnog materijala i teksta. Evidencione liste primenjene su za potrebe utvrđivanja tipova vizuelnog predstavljanja u udžbenicima i frekvencije njihovog pojavljivanja. Takođe, korišćene su i za potrebe utvrđivanja kvaliteta vizuelnog predstavljanja u udžbenicima zemljopisa i poznavanja prirode s aspekta njihove didaktičke funkcionalnosti.

Podaci su obrađeni kvalitativno i kvantitativno. Kvantitativnim putem utvrđeno je u kojoj meri su zastupljeni određeni tipovi vizuelnog predstavljanja. Klaster analizom grupisana su ikonička sredstva izražavanja. Kvalitativna obrada podataka poslužila je za potrebe analize udžbenika i dodatnih izvora koji su potpora istraživanju.

\section{REZULTATI ISTRAŽIVANJA I DISKUSIJA}

Tipovi vizuelnog predstavljanja u udžbenicima zemljopisa i poznavanja prirode

Od ukupno 27 pregledanih udžbenika, 12 udžbenika je iz zemljopisa i 15 udžbenika iz poznavanja prirode. Možemo govoriti o udžbenicima čije brojne stranice obiluju sadržajem koji je predstavljen vizuelnim putem. Na Grafikonu 1, koji prikazuje tipove vizuelnog predstavljanja, može se videti da čak $82 \%$ vizuelnih prikaza zauzimaju crteži, 12\% pripada fotografijama, 5\% zauzimaju karte i svega 1\% shema u ovim udžbenicima.

U analiziranom korpusu udžbenika uočava se da su najčešće korišćeni crteži, zatim fotografije, pri čemu je ovaj odnos šest puta veći u korist crteža. Preciznije, crteži su najdominantniji tip vizuelnog predstavljanja u udžbenicima zemljopisa i poznavanja prirode. „Crteži su manje realistični od fotografija, ali mogu da predstavljaju adekvatniji način prikazivanja 
stvarnosti, jer iz njih mogu da se isključe nebitni detalji a naglase bitni““ (Gašić Pavišić, 2001: 172).

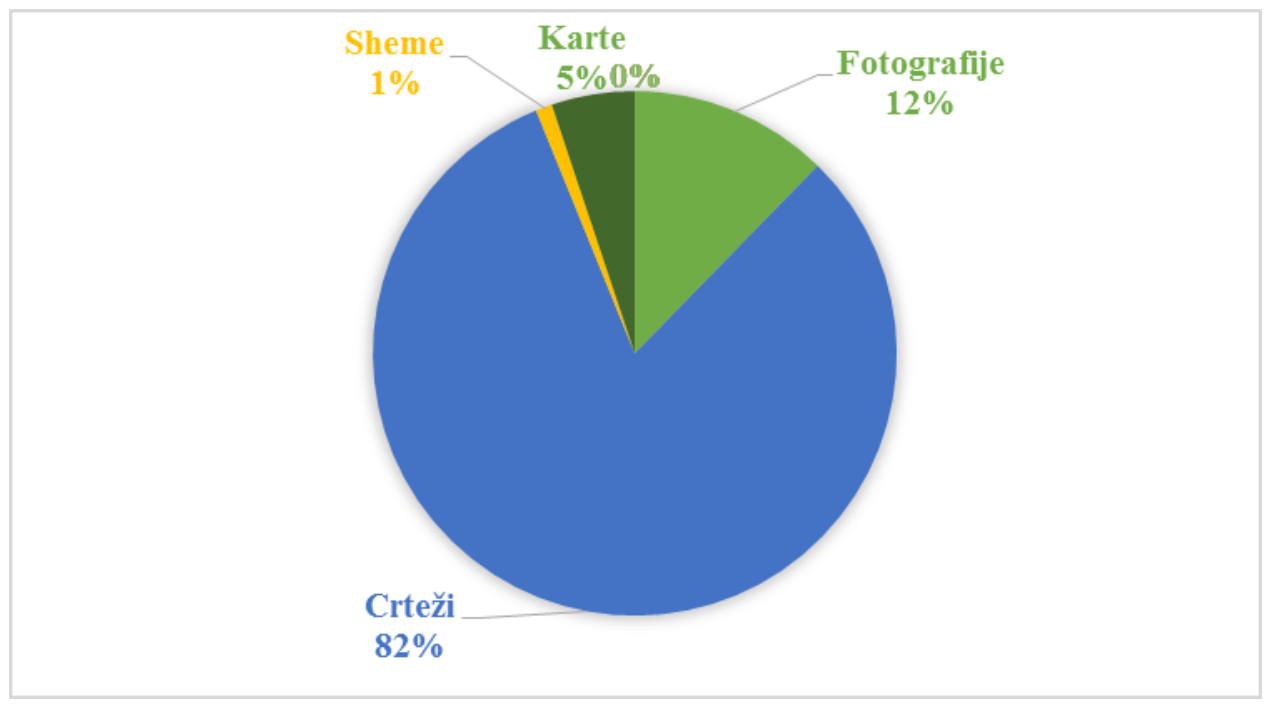

Grafikon 1. Tipovi vizuelnog predstavljanja u udžbenicima zemljopisa i poznavanja prirode

Tokom analize važna su sledeća pitanja: Kojim tipom vizuelnog predstavljanja se najčešće prikazuje gradivo? Da li se javljaju razlike među razredima? Ukoliko razlike postoje, kakve su i šta podrazumevaju? Odgovori na ova pitanja razmatraju se i daju u tekstu koji sledi.

Na osnovu podataka prikazanih na Grafikonu 1, uočava se da autori ovih udžbenika daju prednost delimično realističnim vizuelnim prikazima. Vidi se razlika između udžbenika zemljopisa za III i IV razred, tako da u udžbenicima za IV razred autori daju prednost realističnim vizuelnim prikazima (fotografije). $\mathrm{Na}$ osnovu razlika koje su se pojavile, može se pretpostaviti da je kriterijum biranja proizlazio iz ugla ličnih preferencija samih autora, kao i prilagođenosti određenog tipa vizuelnog predstavljanja 
uzrastu učenika. Kada se govori o prilagođenosti određenog tipa vizuelnog predstavljanja uzrastu učenika, misli se, pre svega, na sposobnost dece da tumače vizuelne znakove; tako, do 10. godine deca imaju teškoće u samostalnom korišćenju konvencionalnih vizuelnih znakova - tabela, grafikona, shema. Nakon tog doba, raste sposobnost za dekodiranje takvih znakova (Gašić Pavišić, 2001). Iz tih razloga, opravdane su razlike koje se javljaju u pogledu dominatnog tipa vizuelnog predstavljanja u udžbenicima zemljopisa, jer se broj konvencionalnih vizuelnih znakova povećava tek u IV razredu. Za mlađu decu su podesnije ilustracije koje opisuju stvarnost jer je to u skladu sa karakteristikama razvoja njihovog logičkog mišljenja (stadijum konkretnih misaonih operacija) (Gašić Pavišić, 2001).

Ilustracije imaju važnu ulogu u razvoju mentalnih funkcija, naročito mišljenja. Na primer, „čitanje“ crteža zahteva misaono angažovanje učenika odnosno uključuje različite operacije logičkog mišljenja. Uočava se da autori udžbenika iz tih razloga na mlađim uzrastima, u najvećem broju slučajeva, koriste crteže i njima „učeniku naglašavaju bitne a isključuju nebitne detalje i tako omogućavaju da se olakša ne samo identifikovanje prikazanih predmeta, već, pre svega uočavanje bitnih svojstava" (Gašić Pavišić, 2001: 172).

Kvalitet vizuelnog predstavljanja u udžbenicima zemljopisa i poznavanja prirode sa aspekta njihove didaktičke funkcionalnosti

U udžbenicima obuhvaćenim istraživanjem zapaža se da ikonička sredstva izražavanja ostvaruju sve tri funkcije a to su: saznajna, estetska i motivaciona i afektivna funkcija. Razmatranjem osnovnih karakteristika ikoničkih sredstava koje ostvaruju navedene funkcije utvrđuje se njihov 
kvalitet s aspekta didaktičke funkcionalnosti. Osnovne karakteristike funkcija ikoničkih sredstava izražavanja jesu:

- vrsta ilustracija u procesu saznavanja,

- apstraktnost ilustrativnog materijala u udžbenicima,

- prikladnost natpisa ispod ikoničkih sredstava izražavanja i

- povezanost ikoničkih sredstava izražavanja i teksta.

U udžbenicima zemljopisa situacija je sledeća: saznajnu funkciju vrši 73\% ikoničkih sredstava izražavanja, 19\% vizuelnih prikaza pripada estetskoj funkciji, 8\% vizuelnih prikaza ostvaruje motivacionu i afektivnu funkciju. Zatim, u udžbenicima poznavanja prirode podaci su sledeći: saznajnu funkciju vrši 73\% ikoničkih sredstava izražavanja, 15\% ikoničkih sredstava izražavanja ima estetsku funkciju i 12\% vizuelnih prikaza vrši motivacionu i afektivnu funkciju.

Saznajna funkcija ikoničkih sredstava izražavanja

„Ikonička sredstva izražavanja koja ostvaruju saznajnu funkciju pojačavaju očiglednost, bolju percepciju teksta, doprinose boljem razumevanju sadržaja i olakšavaju njegovo usvajanje” (Kocić, 2001: 148). Ostvareni rezultati istraživanja pokazuju da ovu funkciju uglavnom postižu vizuelni prikazi koji pripadaju grupi pomoćnih ilustracija. Prema tome, od ukupnog broja ilustracija koje ostvaruju saznajnu funkciju u udžbenicima zemljopisa, 58\% čine pomoćne ilustracije. „Osnovna funkcija pomoćnih ilustracija je da dopune, konkretizuju, otkriju i emocionalno pojačaju sadržaj teksta i drugih vantekstualnih komponenti, pružajući tako pomoć u njihovom najefikasnijem opažanju i usvajanju u procesu učenja“ (Zujev, 1988: 141). Zatim, od ukupnog broja ilustracija sa saznajnom funkcijom, 35\% čine 
vizuelni prikazi koji pripadaju grupi vodećih ilustracija. Kada je reč o udžbenicima poznavanja prirode situacija je sledeća: od ukupnog broja ilustracija koje ostvaruju saznajnu funkciju u udžbenicima poznavanja prirode, $48 \%$ čine pomoćne ilustracije.

Kada se govori o apstraktnosti ikoničkih sredstava izražavanja koja imaju saznajnu funkciju u udžbenicima zemljopisa, proizlazi: 50\% vizuelnih prikaza koji imaju saznajnu funkciju je delimično realistično, 26\% ilustracija je realistično i $24 \%$ vizuelnih prikaza je apstraktno. Prilikom određivanja nivoa apstraktnosti vizuelnih prikaza u udžbenicima poznavanja prirode, utvrđeno je da je 95\% ilustracija predstavljeno delimično realističnim vizuelnim prikazima. Pri određivanju nivoa apstraktnosti vizuelnih prikaza, ključnu ulogu ima odabir tipa vizuelnog predstavljanja gradiva. S obzirom na podatak da u udžbenicima zemljopisa i poznavanja prirode dominira crtež kao tip vizuelnog predstavljanja, onda je očigledno da najveći broj ilustracija prilikom određivanja nivoa apstraktnosti pripada delimično realističnim vizuelnim prikazima. Neki autori ukazuju na to da manje struktuirani vizuelni prikazi (fotografije i crteži) koji preovlađuju u školskim udžbenicima doprinose kognitivnoj obradi obrazovnog sadržaja na samo ograničeni način (Janko \& Knecht, 2014).

Kada je reč o prikladnosti natpisa ispod ilustracija koje imaju saznajnu funkciju na primeru udžbenika zemljopisa, čak 96\% natpisa ispod vizuelnih prikaza samo identifikuje sadržaj. S tim u vezi, može se konstatovati da autori ovih udžbenika daju prednost natpisima koji svojim tekstom samo identifikuju ili pružaju informativnost objekata prikazanih na ilustrativnom materijalu. Situacija se značajno menja kod rezultata dobijenih analizom udžbenika poznavanja prirode. Podaci su sledeči: 64\% natpisa 
ispod ilsutrativnog materijala samo identifikuje sadržaj, dok u 24\% slučajeva nema nikakvog natpisa ispod ilustrativnog materijala; $8 \%$ natpisa je prošireno odnosno svojim tekstom uključuje dodatne informacije o prikazanom objektu koje nisu prezentovane u glavnom tekstu. S obzirom na to da ove ilustracije ostvaruju saznajnu funkciju, veliki je broj onih koje nemaju nikakav natpis. Takva situacija može zbuniti učenika i otežati mu sam proces učenja. U nekim slučajevima natpisi mogu čak uputiti na određeno stanovište i na taj način pružiti pomoć učenicima u tumačenju sadržaja (Janko \& Knecht, 2014).

Kada se govori o povezanosti ikoničkih sredstava koja imaju saznajnu funkciju, s jedne, i teksta u udžbenicima zemljopisa, s druge strane, ostvaruje se jasna povezanost sa tekstom u 94\% slučajeva, a u 6\% slučajeva nejasna je povezanost sa tekstom. Može se konstatovati da je ovakvo stanje zadovoljavajuće. Povezanost ikoničkih sredstava koja imaju saznajnu funkciju i teksta u udžbenicima poznavanja prirode - u svih 100\% slučajeva ostvaruje se jasna povezanost sa tekstom. S tim u vezi, konstatacija je da je ovaj didaktički zahtev u tim udžbenicima u potpunosti ispunjen.

\section{Estetska funkcija ikoničkih sredstava izražavanja}

Estetska funkcija je druga prema učestalosti upotrebe u analiziranim udžbenicima. Na primeru ovog istraživanja, ilustracije koje vrše estetsku funkciju same po sebi stavljene su u kontekst kako bi istakle estetske vrednosti udžbenika. U udžbenicima zemljopisa ovu funkciju ostvaruje 19\% vizuelnih prikaza, dok u udžbenicima poznavanja prirode estetsku funkciju ostvaruje $15 \%$ vizuelnih prikaza. U okviru uzorka koji je obuhvaćen istraživanjem, svih $100 \%$ ilustracija koje ostvaruju ovu funkciju u 
udžbenicima zemljopisa i poznavanja prirode pripada grupi pomoćnih ilustracija. „Smatra se da je to najčešća primena ilustracija i najfrekventnija u kompleksu postojećih školskih udžbenika” (Zujev, 1988: 141).

Kada je reč o apstraktnosti ikoničkih sredstava izražavanja koja imaju estetsku funkciju u udžbenicima zemljopisa, došlo se do toga da je 57\% ikoničkih sredstava izražavanja delimično realistično, a ostalih $43 \%$ pripada realističnim vizuelnim prikazima. U udžbenicima poznavanja prirode $91 \%$ vizuelnih prikaza koji ostvaruju estetsku funkciju delimično je realistično. Može se zapaziti da autori udžbenika u najvećem broju koriste crteže koji imaju dekorativnu ulogu u udžbeniku.

Natpisi ispod ilustracija koje imaju estetsku funkciju u udžbenicima zemljopisa u najvećem broju samo identifikuju sadržaj. Podaci pokazuju da postoji 92\% natpisa koji identifikuju sadržaj u udžbenicima zemljopisa, dok u udžbenicima poznavanja prirode u $68 \%$ slučajeva nema nikakvog natpisa ispod ilustrativnog materijala, a 30\% natpisa samo identifikuje predstavljeni sadržaj. Pretpostavka je da su autori ovih udžbenika težili podizanju estetske vrednosti udžbenika - zanemarujući potrebe učenika.

Vizuelni prikazi koji vrše estetsku funkciju u udžbenicima zemljopisa ostvaruju u 56\% slučajeva nejasnu povezanost sa tekstom, dok u udžbenicima poznavanja prirode u 49\% slučajeva postoji jasna povezanost sa tekstom. Može se konstatovati da je ovaj didaktički zahtev delimično ispunjen. Važno je napomenuti da i u onim situacijama kada se želi naglasiti estetska vrednost udžbenika i podstaći estetski razvoj učenika treba voditi računa o izboru ilustracija tako da budu u jasnoj povezanosti sa gradivom kako ne bi zbunjivale učenika. 


\section{Motivaciona funkcija ikoničkih sredstava izražavanja}

Motivaciona funkcija je treća prema učestalosti upotrebe $u$ analiziranim udžbenicima zemljopisa i poznavanja prirode. U udžbenicima zemljopisa ovu funkciju ostvaruje $8 \%$ vizuelnih prikaza, dok u udžbenicima poznavanja prirode ovu funkciju vrši $12 \%$ ilustracija. Na primeru ovog istraživanja, vidi se da su ilustracije koje vrše ovu funkciju stavljene u udžbenike kako bi zainteresovale i privukle pažnju učenika na nastavni sadržaj.

U udžbenicima zemljopisa i u udžbenicima poznavanja prirode svih $100 \%$ vizuelnih prikaza sa motivacionom funkcijom pripada grupi pomoćnih ilustracija. Primer ovog istraživanja navodi na zaključak da je ova vrsta ilustracija upotrebljena kako bi se emocionalno pojačao sadržaj teksta i zainteresovao učenika za određeno gradivo.

U udžbenicima zemljopisa $68 \%$ vizuelnih prikaza koji ostvaruju motivacionu funkciju jesu delimično realistični, a ostalih 32\% pripada realističnim vizuelnim prikazima. U udžbenicima poznavanja prirode ne iznenađuje podatak da je 99\% ilustracija koje ostvaruju motivacionu funkciju delimično realistično, jer crtež značajno dominira kao tip vizuelnog predstavljanja gradiva.

Podaci do kojih se došlo analizom udžbenika zemljopisa pokazuju da u 97\% slučajeva natpisi ispod ilustrativnog materijala identifikuju sadržaj, a u udžbenicima poznavanja prirode u $68 \%$ slučajeva. S obzirom na to da motivaciona funkcija ima za cilj da zainteresuje učenike za nastavni sadržaj, može se reći da su ovakvi natpisi ispod ilustrativnog materijala koji ostvaruju motivacionu funkciju zadovoljavajući. 
Vizuelni prikazi koji ostvaruju motivacionu funkciju u udžbenicima zemljopisa u $82 \%$ slučajeva imaju jasnu povezanost sa tekstom, a u $18 \%$ slučajeva ostvaruju nejasnu povezanost sa tekstom, dok se u udžbenicima poznavanja prirode u 99\% slučajeva ostvaruje jasna povezanost sa tekstom. $\mathrm{Na}$ osnovu dobijenih podataka, konstatuje se da je u većem broju slučajeva stanje zadovoljavajuće, ali ne sme se zanemariti ovih 18\% slučajeva jer mogu dovesti učenika u konfuziju ukoliko tekst i ilustracija nisu u jasnoj povezanosti.

Stanovište o vizuelnom predstavljanju u praktičnim priručnicima za učitelje

A sada nešto o zaključcima do kojih se došlo analizom metodskih uputstava za učitelje. Proučavajući stanovište o vizuelnom predstavljanju u metodskim uputstvima za učitelje, zaključuje se da se ikoničkim sredstvima izražavanja ne posvećuje velika pažnja. Imajući na umu pretpostavku koliko je u to vreme školski udžbenik bio važno sredstvo informacija a da su ikonička sredstva izražavanja činila njegov veliki i značajan deo, uverenje je da u ovim priručnicima nedostaju neophodna uputstva kako efikasno koristiti ilustrativni materijal iz udžbenika za rad na času. Uz to, autori ovih priručnika uočili su i isticali važnost ilustrativnog materijala u saznajnom procesu, ali samo u onom segmentu kako bi učitelju olakšali razumevanje iznetih uputstava. Ukoliko se na umu ima i uzrast učenika kojima su namenjeni udžbenici obuhvaćeni ovim istraživanjem, mora se obratiti pažnju i na pitanje kako učenicima pomoći u korišćenju ilustrativnog materijala iz udžbenika. To pitanje je važno jer obuhvaćeni hronološki raspon polazi od mlađeg školskog uzrasta, kada učeniku treba da budu jasna i razumljiva uputstva kojima počinje da usvaja osnove saznavanja sveta koji ga okružuje. 


\section{ZAKLJUČAK}

S obzirom na period kada su nastali i kada su se koristili, udžbenici zemljopisa i poznavanja prirode bili su izuzetno važni u procesu učenja. Oni su ponudili širok spektar osnovnih pojmova za uzrast kojem su namenjeni a učiteljima pružili potporu u realizaciji nastave. Prema savremenim gledištima, udžbenik je viđen kao neizostavno i važno sredstvo informisanja. $\mathrm{Na}$ osnovu toga, može se zamisliti koliko je bila važna uloga udžbenika u periodu od 1945. do 1966. godine, kada nije bilo interneta i kada su sva znanja bila dostupna jedino u knjigama.

Jasno je da su ovakva istraživanja u našoj oblasti potrebna i značajna. $\mathrm{S}$ tim u vezi, komparativna proučavanja u okviru ove tematike bila bi od izuzetne važnosti. Kao primer, moglo bi se izvršiti proučavanje udžbenika zemljopisa i poznavanja prirode među zemljama bivše Jugoslavije. Takođe, mogla bi se načiniti istraživanja koja bi obuhvatala uporednu analizu ovih udžbenika i udžbenika iz savremene perspektive.

$\mathrm{Na}$ samom kraju, ne treba zaboraviti da je proučavanje tipova vizuelnog predstavljanja u udžbenicima itekako značajno ukoliko se na umu ima da veliki deo udžbenika pripada upravo različitim ikoničkim sredstvima izražavanja. S obzirom na funkciju koju ikonička sredstva izražavanja ostvaruju u saznajnom procesu, potreba za njihovim daljim istraživanjem je neophodna. 


\section{VISUAL REPRESENTATION IN GEOGRAPHY TEXTBOOKS AND TEXTBOOKS OF NATURE IN SERBIA FROM 1945 TO 1966}

\section{Abstract}

Contemporary viewpoint textbooks are seen as an indispensable and important source of information. Visual representation implies the key structural elements in the textbooks. The aim of the paper was to determine the characteristics of visual representation in geography textbooks and textbooks of nature for elementary school from 1945 to 1966 The paper summarizes the most important results and conclusions obtained in this research. Having in mind the chronological period when the geography textbooks and textbooks of nature were created and used, they were of a great importance for the learning process. Studying different types of visual representation in textbooks in the previous days and today is of a great importance for improving the teaching process.

Key words: visual representation, illustrative material, pedagogical history, geography textbooks, textbooks of nature. 


\section{REFERENCE}

Čalić, M.-Ž. (2013). Istorija Jugoslavije u 20. veku. Beograd: Clio.

Gašić Pavišić, S. (2010). Likovno-grafička oprema udžbenika; u B. Trebješanin i D. Lazarević (prir.) Savremeni osnovnoškolski udžbenik: teorijsko-metodološke osnove (171-185). Beograd: Zavod za udžbenike i nastavna sredstva.

Ilić Rajković, A. i M. Senić Ružić (2016). Proučavanje udžbenika i pedagoška prošlost: prikaz savremenih metodoloških pristupa. Nastava $i$ vaspitanje, god. 65, br. 3, 555-568.

Ivić, I. A. Pešikan i S. Antić (2008). Vodič za dobar udžbenik: opšti standardi kvaliteta udžbenika. Novi Sad: Platoneum.

Janko, T. \& P. Knecht (2014). Visuals in Geography Textbooks: Increasing the Reliability of a Research Instrument; in E. Matthes (Ed.): Metodology and Methods of Research on Textbooks and Educational Media (227-240). Julius Klinkhard: Bad Heilbrunn.

Kocić, Lj. (2001). Didaktičko-metodički zahtevi u oblikovanju structure udžbenika; u B. Trebješanin i D. Lazarević (prir.) Savremeni osnovnoškolski udžbenik: teorijsko-metodološke osnove (131-156). Beograd: Zavod za udžbenike i nastavna sredstva.

Mahamud, K. (2014). Contexts, Texts and Representativeness: A Methodological Approach to School Textbook Research; in E. Matthes (Ed.) Metodology and Methods of Research on Textbooks and Educational Media (31-49). Julius Klinkhard: Bad Heilbrunn.

Pingel, F. (2010). UNESCO Guidebook on Textbook Research and Textbook Revision. Paris/Braunschweig: UNESCO and the Georg Eckert Institute for International Textbook research.

Tešić, V. i dr. (1980). Sto godina Prosvetnog saveta Srbije. Beograd: Zavod za udžbenike i nastavna sredstva.

Zujev, D. (1988). Školski udžbenik. Beograd: Zavod za udžbenike i nastavna sredstva. 
